\title{
Documenting the suboxic zone of the Black Sea via high-resolution real-time redox profiling
}

\author{
Brian T. Glazer ${ }^{\mathrm{a}, 1}$, George W. Luther III', ${ }^{\mathrm{a}, *}$, Sergey K. Konovalov, \\ Gernot E. Friederich ${ }^{\mathrm{c}}$, Donald B. Nuzzio ${ }^{\mathrm{d}}$, Robert E. Trouwborst ${ }^{\mathrm{a}}$, \\ Bradley M. Tebo ${ }^{\mathrm{e}, 2}$, Brian Clement ${ }^{\mathrm{e}}$, Karen Murray ${ }^{\mathrm{e}}$, Alexander S. Romanov ${ }^{\mathrm{b}}$ \\ ${ }^{a}$ College of Marine Studies, University of Delaware, Lewes, DE 19958, USA \\ ${ }^{\mathrm{b}}$ Marine Hydrophysical Institute, Kapitanskaya 2, Sevastopol 99011, Ukraine \\ ${ }^{\mathrm{c}}$ MBARI, 7700 Sandholdt Road, Moss Landing, CA 95039, USA \\ d Analytical Instrument Systems, Inc., 1059C Old York Road, Ringoes, NJ 08851, USA \\ e Scripps Institution of Oceanography, University of California, San Diego, CA 92093, USA
}

Received 1 November 2003; accepted 28 March 2006

Available online 6 September 2006

\begin{abstract}
We coupled an in situ electrochemical analyzer to a CTD pump profiler system to measure redox species across the oxic-anoxic interface of the Black Sea water column. Voltammetry was performed using gold-amalgam working electrodes to measure simultaneously oxygen and dissolved sulfur species $\left(\mathrm{S}_{8}, \mathrm{~S}_{x}^{2-}, \mathrm{HS}^{-} / \mathrm{H}_{2} \mathrm{~S}\right)$ both in situ (at $<1 \mathrm{~m}$ vertical intervals) and in an on-deck flow cell attached to the outflow of a pump profiler (vertical resolution of about $1.5 \mathrm{~m}$ ). In situ data agreed with measurements made in the flow cell and with measurements made from samples collected by rosette bottle casts. In situ voltammetry provided undisturbed, high-resolution measurements, and revealed significant yet subtle features not seen by traditional methods because of small spatial separation between the features and the measurements. Layers of oxygen intrusion $\left(<5 \mathrm{~m}\right.$ thick, from 10 to $150 \mu \mathrm{M} \mathrm{O}_{2}$ ) were present within the suboxic zone of the southwest Black Sea that are not present in the west-central and northeast Black Sea. Oxygen injection also occurs at other depths throughout the southwest and corresponds with small temperature anomalies, suggesting influence by Bosporus inflow up to $150 \mathrm{~km}$ from its entrance to the Black Sea. Such an inflow of oxygen, as well as spatial variations of the halocline, affect both manganese and, subsequently, sulfide oxidation for a large portion of Black Sea intermediate water $\left(\mathrm{H}_{2} \mathrm{~S}\right.$ onset occured $\sim 60 \mathrm{~m}$ deeper in the southwest as compared to the west-central). In situ voltammetric analyses provided rapid redox information, thus enabling more accurate targeting of specific geochemical features by the CTD rosette package.
\end{abstract}

(C) 2006 Elsevier Ltd. All rights reserved.

Keywords: In situ voltammetry; Oxygen; Sulfide; Suboxic; Black Sea; Redox

\footnotetext{
*Corresponding author. Tel.: + 13026454208 ; fax: +13026454007 .

E-mail address: luther@udel.edu (G.W. Luther III).

${ }^{1}$ Present address: Department of Oceanography, University of Hawaii, Honolulu, HI 96822, USA.

${ }^{2}$ Present address: Oregon Graduate Institute, Oregon Health \& Science University, Beaverton, OR 97006, USA.
}

\section{Introduction}

Oxygen and sulfide were commonly thought to coexist in the transition from oxic to sulfidic waters in the Black Sea (Sorokin, 1983; Faschuck and Ayzatullin, 1986), until 1988 when a suboxic zone 
with nondetectable levels of $\mathrm{O}_{2}$ and $\mathrm{H}_{2} \mathrm{~S}$ (Murray et al., 1989) was observed. More recent studies have confirmed vertical separation between oxygen and sulfide in the Black Sea water column (Tugrul et al., 1992). Natural barriers inhibiting vertical fluxes are established through density stratification of the water column (Sorokin, 1983; Anderson et al., 1988; Murray et al., 1995; Pers and Rahm, 2000; Scranton et al., 2001), caused by sharp increases in salinity (Anderson et al., 1988) and/or decreases in temperature (Scranton et al., 2001). In the case of the Black Sea, a vertical transition between oxic and anoxic waters is likely to have existed for over 7000 years (Arthur and Dean, 1998; Lane-Serff et al., 1997), since post-glacial saline Mediterranean waters broke through a land barrier and flooded the isolated freshwater Black Sea basin at a rate of 0.1-1 $\mathrm{m}$ per day, setting up a permanent pycnocline. The nature of the physical stratification and the subsequent steep chemical gradients make accurate sampling of these constituents around the redox transition problematic, yet crucial to understanding the overall redox budget of the Black Sea.

Traditional methods for water sampling use casts with bottles mounted on a CTD rosette. Such rosette casts induce water mixing during the upward and downward motion through the water column. Furthermore, water samples are collected in vertically oriented bottles, which integrate waters over a vertical distance of greater than a meter. In 1988, a pump profiling system was deployed in the Black Sea (Codispoti et al., 1991) to provide continuous vertical profiling capability, but, again, mixing may be induced through pumping of water from depth to the ship's lab through $200 \mathrm{~m}$ of nylon tubing. Reactions may occur as a result of particulate adhesion to the tubing walls. Modern deployable voltammetric analyzers coupled to $\mathrm{Au} / \mathrm{Hg}$ electrodes recently have been used to characterize $\mathrm{O}_{2}$, $\mathrm{H}_{2} \mathrm{O}_{2}, \mathrm{H}_{2} \mathrm{~S}, \mathrm{~S}_{x}^{2-}$, soluble $\mathrm{S}_{8}, \mathrm{Fe}(\mathrm{II}), \mathrm{Fe}(\mathrm{III})$, aqueous $\mathrm{FeS}, \mathrm{Mn}(\mathrm{II})$ in salt marsh (Bull and Taillefert, 2001), continental shelf sediments and coastal bays (Luther et al., 1999), microbial mats (Glazer et al., 2002), and hydrothermal vents (Luther et al., 2001a,b). Such sensors are capable of making realtime, in situ measurements, independent of sample manipulation, thus providing unprecedented vertical resolution for redox profiling.

Our objective was to apply in situ voltammetric techniques to measure $\mathrm{O}_{2}$ and $\mathrm{H}_{2} \mathrm{~S}$ (detection limits of $3 \mu \mathrm{M}$ and $30 \mathrm{nM}$, respectively), as well as other partially oxidized sulfur species (Brendel and
Luther, 1995; Luther et al., 2001a,b), and provide high-resolution vertical profiling of the oxic-suboxic-sulfidic transition in the Black Sea water column. In addition, an electrochemical flow cell (Luther et al., 2002) was connected to the pump profiler outflow to allow for comparison measurements between in situ and on-deck samples. Data from both of these were compared with data obtained through traditional Winkler (for $\mathrm{O}_{2}$ ) and iodometric titrations (for $\mathrm{H}_{2} \mathrm{~S}$ ) of samples taken from separate bottle casts.

We confirm the existence and define the extent and variability of the suboxic zone throughout the western Black Sea. We also demonstrate the existence of partially oxidized sulfur intermediates at depths near the onset of $\mathrm{H}_{2} \mathrm{~S}$, and report evidence for lateral intrusions of oxygen-enriched waters into suboxic and anoxic layers using data from the Black Sea cruise on the R.V. Knorr (23 May-9 June 2001). We also compare these results with selected data from the 1988 R.V. Knorr cruise where the pump profiler system was employed with shipboard hanging mercury drop voltammetry measurements that had a minimum detection limit of $0.1 \mathrm{nM}$ for sulfide, as reported by Luther et al. (1991).

\section{Methods}

Stations within the western Black Sea were occupied during R.V. Knorr Voyage 162-legs 16 and 17, between 23 May and 11 June 2001 (Fig. 1). Data were collected to provide new insight and comparisons to the previous major US Black Sea expedition, conducted in 1988 (R.V. Knorr Voyage 134, April-July 1988; Murray et al., 1989; Fig. 2).

\subsection{Profiling instrument package}

The deployment package consisted of two separate instruments attached to a protective stainless steel cage. Temperature, salinity, density, and ondeck flow-through water samples were provided by the pump profiler-CTD system developed by the Monterey Bay and Aquarium Institute (MBARI) (Codispoti et al., 1991). In situ voltammetric analyses were conducted using an electrochemical analyzer built into a pressure housing (Analytical Instrument Systems, Inc.) powered by an internal rechargeable $12 \mathrm{~V}$ DC battery. The internal computer communicated with another aboard the ship via a 300-m RS 232 cable and was controlled by an operator or programmed to continuously perform 


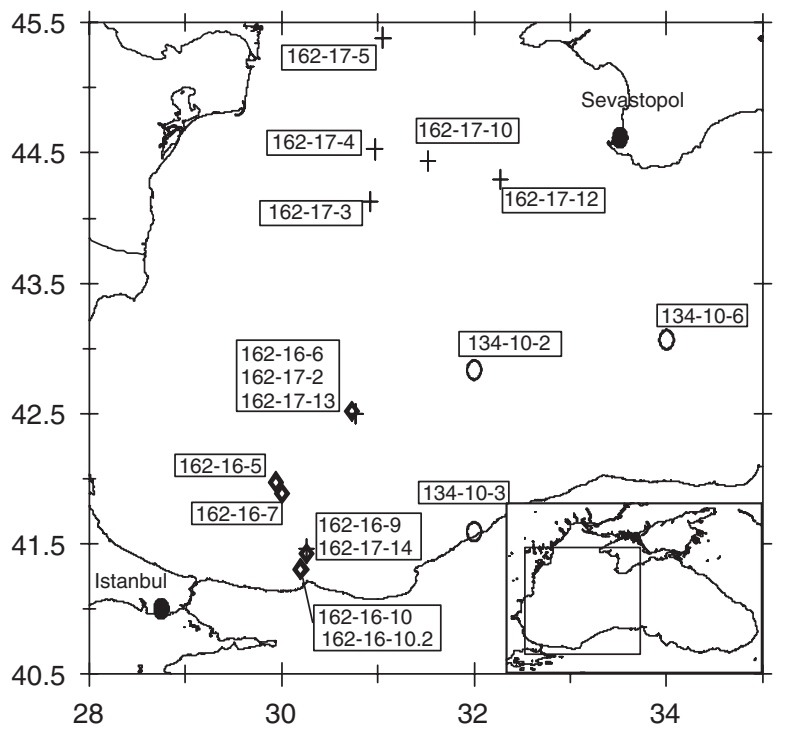

Fig. 1. Selected station locations for the 2001 and 1988 R.V. Knorr Black Sea cruises (Voyage 134-10, June 1988, marked by circles; Voyage162-16, 23-31 May 2001, marked by diamonds; Voyage162-17, 1-9 June 2001, marked by crosses). Lower right inset locates the area of investigation.

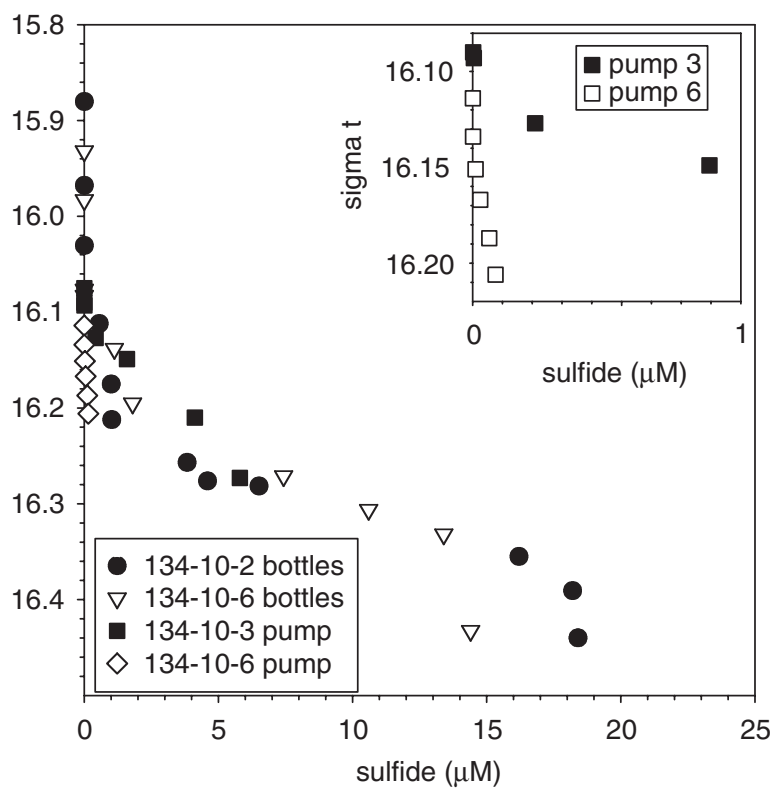

Fig. 2. Interface data for $\mathrm{H}_{2} \mathrm{~S}$ from stations occupied by R.V. Knorr in 1988. The inset magnifies pump profiler data from the interface.

voltammetric measurements. A separate 1-m cable was used to make connections between the working, reference, and counter electrodes and the pressure housing. This cable accommodated up to four different working electrodes that were used via an internal multiplexer, the counter electrode, and two inputs for the reference electrode so that it could be grounded to ensure signal integrity.

\subsection{In situ electrochemical analyses}

The working electrodes were solid-state goldamalgam $(\mathrm{Au} / \mathrm{Hg})$ and were prepared in polyethyletherketone $\left(\mathrm{PEEK}^{\mathrm{TM}}\right.$ ) tubing, sealed with epoxy (Luther et al., 1999). The reference electrode was also solid-state, prepared by oxidizing a $500-\mu \mathrm{m}$ silver wire in $3 \mathrm{M} \mathrm{KCl}$ to make an $\mathrm{AgCl}$ coating. Potentials for chemical species measured in situ and onboard ship with the same reference electrode were comparable so no pressure effects were observed. Scan rates were $1000 \mathrm{mV} \mathrm{s}^{-1}$. Prior to each scan, conditioning was performed at $-0.9 \mathrm{~V}$ for $5 \mathrm{~s}$, where none of the chemical species are electroactive (Brendel and Luther, 1995), and then a 2-s deposition at $-0.1 \mathrm{~V}$. Potential scan direction was from positive to negative for linear sweep voltammetry (LSV). Cyclic voltammetry (CV) scans were from positive to negative and then back to positive. These conditions provided a detection limit of $30 \mathrm{nM}$ for $\mathrm{H}_{2} \mathrm{~S}$ and about $3 \mu \mathrm{M}$ for $\mathrm{O}_{2}$, as determined by linear regression of known standards. Such low detection levels allowed for the in situ identification of irregular multi-layer vertical structure for chemical species, which cannot be detected by traditional methods. Because voltammetric scans could be performed every $9 \mathrm{~s}$ or less, measurements were made every 0.8 meter or less based on the descent rate of the MBARI-AIS package through the water column.

At the working electrode surface, $\mathrm{O}_{2}$ is electrochemically reduced to $\mathrm{H}_{2} \mathrm{O}_{2}$ at a half-wave potential $E_{1 / 2}=-0.3 \mathrm{~V}$, and the $\mathrm{H}_{2} \mathrm{O}_{2}$ is subsequently reduced at $E_{1 / 2}=-1.3 \mathrm{~V}$, as seen in oxygenated waters above $130 \mathrm{~m}$ in the southwest (Fig. 3A-C). The magnitude of the current for the voltammetric wave is proportional to the concentration of oxygen present.

\subsection{Discrete sampling and analyses}

Aboard ship, a DLK-60 electrochemical analyzer (AIS, Inc.) controlled similar solid-state $\mathrm{Au} / \mathrm{Hg}$ working, $\mathrm{Ag} / \mathrm{AgCl}$ reference, and $\mathrm{Pt}$ counter electrodes within a flow cell (Luther et al., 2002) attached to outflow from the pump profiling system. Typical conditions were a potential scan range from 

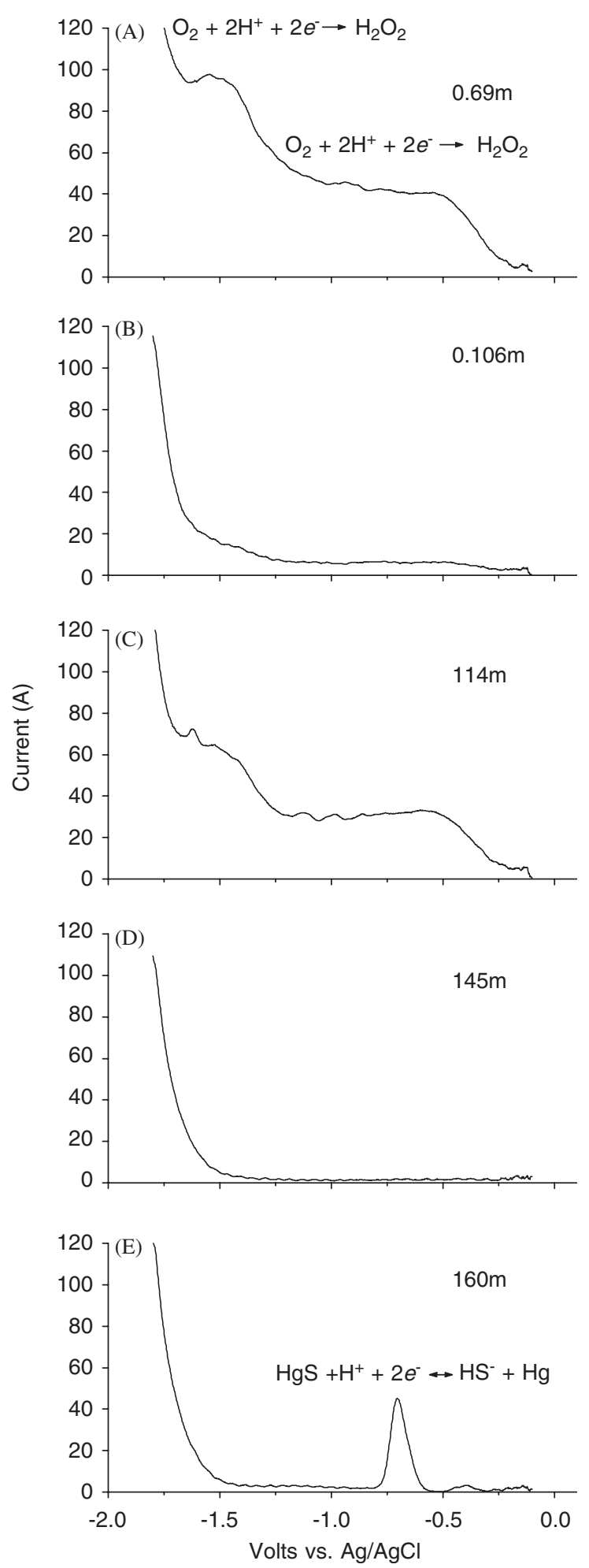

Fig. 3. Representative voltammograms acquired with the in situ electrochemical analyzer depicting vertical structure within the suboxic zone due to inflowing Bosporus waters at Station 162-169, on 29 May 2001.
-0.1 to $-1.8 \mathrm{~V}$ using $\mathrm{LSV}$ or $\mathrm{CV}$ modes at 1 or $4 \mathrm{Vs}^{-1}$. The working electrode was conditioned at $-0.9 \mathrm{~V}$ for $2 \mathrm{~s}$ to clean the $\mathrm{Au} / \mathrm{Hg}$ surface, and then a deposition step at $-0.1 \mathrm{~V}$ for $5-20 \mathrm{~s}$ was performed. These conditions provided the low detection limit of $3 \mathrm{nM}$ for $\mathrm{H}_{2} \mathrm{~S}$ and about $3 \mu \mathrm{M}$ for $\mathrm{O}_{2}$.

Bottle casts were taken immediately before and/ or after the in situ profiles. Water samples from discrete bottles were analyzed by Winkler titration for $\mathrm{O}_{2}$ (detection limit $\sim 3 \mu \mathrm{M}$ ) and by iodometric titration (detection limit $\sim 3 \mu \mathrm{M}$ ) and voltammetry (detection limit $\sim 3 \mathrm{nM}$ ) for $\mathrm{H}_{2} \mathrm{~S}$. Measurements were made for particulate $(>0.22 \mu \mathrm{m})$ and dissolved Mn from samples collected from Niskin bottles and filtered according to Tebo (1991). Mn in each fraction was determined using the formaldoxine method (Brewer and Spencer, 1971). Particulate elemental sulfur $\left(\mathrm{S}_{8}\right)$ was analyzed by ion chromatography after gravity filtering $200-\mathrm{ml}$ samples from a Niskin bottle through a $0.2-\mu \mathrm{m}$ polycarbonate filter. Filters were kept frozen $\left(-20^{\circ} \mathrm{C}\right)$ until they were extracted in $5-\mathrm{mM}$ sulfite solution for $2.5 \mathrm{~h}$ to react all elemental sulfur with sulfite to thiosulfate (Luther et al., 1991). The method of (Rozan and Luther, 2001) was adapted for thiosulfate analysis using anion chromatography with subsequent spectroscopic detection at a wavelength of $215 \mathrm{~nm}$. The elutent was $8 \mathrm{mM}$ perchlorate, at a flow rate of $2 \mathrm{ml} /$ min. Thiosulfate retention time was $7.3 \mathrm{~min}$.

\section{Results and discussion}

During 23 May-9 June 2001, the R.V. Knorr occupied 24 stations chosen to investigate oxidation dynamics across a region influenced by the inflowing Bosporus Plume. Data from 15 stations are presented here and compared to three stations from the 1988 cruise (Fig. 1). The complete list of participants, stations and data for R.V. Knorr 2001 is given at www.ocean.washington.edu/ cruises/Knorr2001. Water entering the Black Sea through the Bosporus Strait $(32 \mathrm{~m}$ water depth at sill) is more saline and warmer $\left(12.5-15^{\circ} \mathrm{C}\right)$ than the water it entrains from the Black Sea cold intermediate layer $(\mathrm{CIL})\left(<8^{\circ} \mathrm{C}\right)$. These mixed waters create a plume that is injected into layers of the Black Sea below the CIL (Murray et al., 1991), and have been traced to depths of $500-700 \mathrm{~m}$ via temperature anomalies (Oguz and Rozman, 1991). This influx of salt is the mechanism for maintaining the main pycnocline of the Black Sea. 


\subsection{Oxygen and sulfide distributions}

Sulfide data are plotted versus density $\left(\sigma_{\mathrm{t}}\right)$ for selected stations from the 1988 R.V. Knorr cruise (Fig. 2). At all stations the onset of $\mathrm{H}_{2} \mathrm{~S}$ occurred near $\sigma_{\mathrm{t}}=16.1$ (Murray et al., 1995). However, a near-shore location (station 134-10-3) showed a 10fold or higher sulfide concentration than those observed at the two central locations (stations 13410-2 and 134-10-6). The samples collected by bottle casts in 1988 had a 5-m vertical resolution and the pump-profiler samples had a 2-m vertical resolution. Interestingly, the sulfide data taken from bottle casts were higher than those from the pump profiler. This may be due to the $1-\mathrm{m}$ length of the bottles that result in water samples with a poorer vertical resolution than the pump profiler, which has a 6$\mathrm{mm}$ diameter orifice at its pump intake.

Based on data in Fig. 2, we decided to design and build an in situ chemical analyzer to determine dissolved $\mathrm{O}_{2}$ and $\mathrm{H}_{2} \mathrm{~S}$ and other redox components (Table 1). Deployment of this instrument in 2001 provided in situ voltammetric profiles that helped to document lateral $\mathrm{O}_{2}$ injection from the Bosporus Plume (Konovalov et al., 2003). This lateral injection suppresses and distorts the suboxic zone and the upper part of the $\mathrm{H}_{2} \mathrm{~S}$ onset at stations influenced by Bosporus inflow throughout the southwest Black Sea, as observed in oxygenated waters above $130 \mathrm{~m}$ in the southwest (Fig. 3A-C). Oxygen concentration is 6 times as high (roughly $40 \mathrm{nA}$ of current, or $150 \mu \mathrm{M}$ ) at $69 \mathrm{~m}$, than at $106 \mathrm{~m}$ (roughly $6 \mathrm{nA}$ of current, or $20 \mu \mathrm{M}$ ). An increase in signal current (roughly $40 \mathrm{nA}$, or $150 \mu \mathrm{M}$ ) signifies an increase in oxygen concentration at $114 \mathrm{~m}$ (Fig. 3C), and there is no detectable oxygen signal at $145 \mathrm{~m}$ (Fig. 3D). By $160 \mathrm{~m}, \mathrm{H}_{2} \mathrm{~S}\left(E_{1 / 2}=-0.6 \mathrm{~V}\right.$; Fig. 3E, Table 1) is detected.

Oxygen and sulfide profiles for the southwestern station (Fig. 4), from which the voltammograms in Fig. 3 were taken, reveal the degree of vertical structure for the lateral injections. The profiles are plotted against depth to emphasize the narrowness of the lateral intrusions and to match the voltammograms shown in Fig. 3. Intrusions were identified in several individual profiles as narrow local anomalies, three of which can be clearly seen in Fig. 4A and B (84.8-99.6, 110-121, 121-129 m). Fig. $4 \mathrm{~B}$ is an enlarged view of the full profile in Fig. 4A, and more clearly shows the lateral injections. Oxygen concentrations reflect the same oscillating pattern seen in the voltammetric scans from Fig. 3. In addition, a sharp decrease in sulfide concentration, accompanied by a small temperature increase (162-178 m) following the $\mathrm{H}_{2} \mathrm{~S}$ onset $\left(151 \mathrm{~m}\right.$, or $\sigma_{\mathrm{t}}$ of 16.13) suggests that a deeper oxidation intrusion occurred. Such variable, dynamic lateral injections were likely the reason that a well-defined

Table 1

Measurable redox reactions occurring at the $0.1 \mathrm{~mm} \mathrm{Au} / \mathrm{Hg}$ electrode surface vs. the $0.5 \mathrm{~mm} \mathrm{Ag} / \mathrm{AgCl}$ reference electrode

\begin{tabular}{llll}
\hline & & $E_{\mathrm{p}}\left(E_{1 / 2}\right)(\mathrm{V})$ & $\mathrm{MDL}(\mu \mathrm{m})$ \\
\hline $1 \mathrm{a}$ & $\mathrm{O}_{2}+2 \mathrm{H}^{+}+2 \mathrm{e}^{-} \rightarrow \mathrm{H}_{2} \mathrm{O}_{2}$ & -0.30 & 5 \\
$1 \mathrm{~b}$ & $\mathrm{H}_{2} \mathrm{O}_{2}+2 \mathrm{H}^{+}+2 \mathrm{e}^{-} \rightarrow \mathrm{H}_{2} \mathrm{O}$ & -1.2 & 5 \\
$2 \mathrm{a}$ & $\mathrm{HS}^{-}+\mathrm{Hg} \rightarrow \mathrm{HgS}+\mathrm{H}^{+}+2 \mathrm{e}^{-}$ & Adsorption onto $\mathrm{Hg}<-0.60$ & $<0.1$ \\
$2 \mathrm{~b}$ & $\mathrm{HgS}+\mathrm{H}^{+}+2 \mathrm{e}^{-} \rightarrow \mathrm{HS}^{-}+\mathrm{Hg}$ & $\sim-0.60$ & $<0.1$ \\
$3 \mathrm{a}$ & $\mathrm{S}^{0}+\mathrm{Hg} \rightarrow \mathrm{HgS}$ & Adsorption onto $\mathrm{Hg}<-0.60$ & \\
$3 \mathrm{~b}$ & $\mathrm{HgS}+\mathrm{H}^{+}+2 \mathrm{e}^{-} \leftrightarrow \mathrm{HS}^{-}+\mathrm{Hg}$ & $\sim-0.60$ & $<0.1$ \\
$4 \mathrm{a}$ & $\mathrm{Hg}+\mathrm{S}_{x}^{2-} \leftrightarrow \mathrm{HgS}_{x}+2 \mathrm{e}^{-}$ & Adsorption onto $\mathrm{Hg}<-0.60$ & $<0.1$ \\
$4 \mathrm{~b}$ & $\mathrm{HgS} \mathrm{S}_{x}+2 \mathrm{e}^{-} \leftrightarrow \mathrm{Hg}+\mathrm{S}_{x}^{2-}$ & $\sim-0.60$ & \\
$4 \mathrm{c}$ & $\mathrm{S}_{x}^{2-}+x \mathrm{H}^{+}+(2 x-2) \mathrm{e}^{-} \leftrightarrow x \mathrm{HS}^{-}$ & $\sim-0.60$ & 5 \\
5 & $\mathrm{Mn}^{2+}+\mathrm{Hg}+2 \mathrm{e}^{-} \leftrightarrow \mathrm{Mn}(\mathrm{Hg})$ & -1.55 & \\
\hline
\end{tabular}

Oxygen data were collected by linear sweep voltammetry. Cyclic voltammetry was employed in the absence of oxygen to better measure sulfur species. Potentials can vary slightly with scan rate and concentration. When applying potential from a positive to negative scan direction, sulfide and $\mathrm{S}(0)$ react in a two step process: adsorption onto the $\mathrm{Hg}$ surface to form $\mathrm{HgS}$, and reduction of the $\mathrm{HgS}$ film. Polysulfides react in a three step process: adsorption onto the $\mathrm{Hg}$ surface to form a $\mathrm{HgS}_{x}$ film, reduction of the $\mathrm{HgS}_{x}$ film, and reduction of the $S(0)$ in the polysulfide. Increasing scan rate separates electrode reactions $4 \mathrm{~b}$ and $4 \mathrm{c}$ into two peaks because reaction $4 \mathrm{c}$ is an irreversible process. Increasing scan rate shifts this signal significantly. MDL $=$ minimum detection limit. 


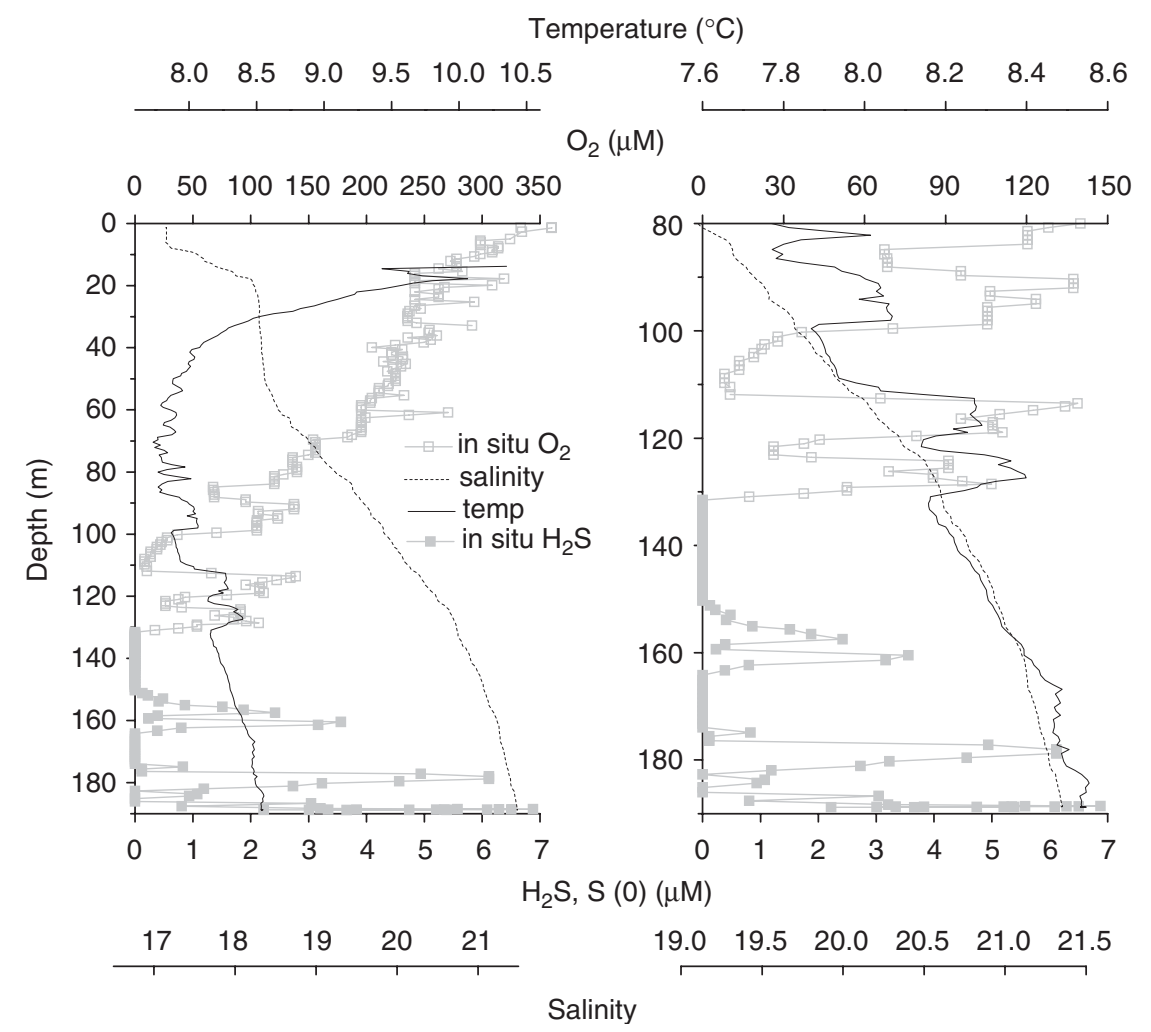

Fig. 4. In situ voltammetry profile of Station 162-16-9, 29 May 2001. Depth versus high-resolution $\mathrm{O}_{2}$ and $\mathrm{H}_{2} \mathrm{~S}$ data coupled to temperature and salinity data from the CTD on the MBARI pump profiler.

suboxic zone is not present in the southwest, but is rather undeveloped and less than $15 \mathrm{~m}$ thick $(\sim 130-145 \mathrm{~m})$.

Our in situ measurements, showed no evidence to suggest that $\mathrm{O}_{2}$ and $\mathrm{H}_{2} \mathrm{~S}$ co-exist (e.g., Sorokin, 1972), as none of over 3000 in situ voltammetric scans showed their simultaneous detection in any of the profiles. Furthermore, these data suggest that $\mathrm{O}_{2}$ penetrates the suboxic zone via lateral mixing from Bosporus inflow and may be suppressing the onset of sulfide to $150-160 \mathrm{~m}$ ( $\sigma_{\mathrm{t}}$ of $\left.16.13-16.23\right)$.

The main pycnocline of the Black Sea is present at water densities of $\sigma_{\mathrm{t}}=14.2-16.5$ and the core of the CIL is at $\sigma_{\mathrm{t}}=14.5$. The Bosporus Plume water is a mixture of 1 volume of the Mediterranean Sea water and 3-10 volumes of Black Sea water (Murray et al., 1991; Ivanov and Samodurov, 2001) so these ventilation layers occur below the CIL $\left(\sigma_{t}>14.5\right)$. Calculations predict the concentration of dissolved $\mathrm{O}_{2}$ within the Bosporus plume should reach 100-150 $\mu \mathrm{M}$ (Konovalov and Murray, 2002), which is the approximate concentration in the observed intrusions. Furthermore, these spikes in $\mathrm{O}_{2}$ concen- tration coincide with small salinity and temperature increases $\left(<0.4^{\circ} \mathrm{C}\right)$, also visible in Fig. 4. The anomalies are more readily seen in temperature, rather than salinity, because the relative differences are larger. Linear regressions between temperature and oxygen for each of the three prominent oxygen injection layers reveal significant positive correlations (Fig. 5A-C) and confirm that the warm, salty Bosporus plume water is the source of the largescale lateral $\mathrm{O}_{2}$ flux into the suboxic and anoxic layers of the pycnocline. These linear correlations suggest that the regime of turbulent diffusion, as opposed to double diffusion, is realized for lateral intrusions of the Bosporus plume. This would hold true for other components as well, i.e. salinity, and is important for understanding dissipation processes of lateral intrusions into the Black Sea ambient waters. It has been argued that physical parameters are adequate tracers of Bosporus inflow (Latif et al., 1991; Schuf and De Baar, 1995), but because the differences in salinity and temperature between the Bosporus plume and the ambient Black Sea water are so small and oxygen concentrations differ by 

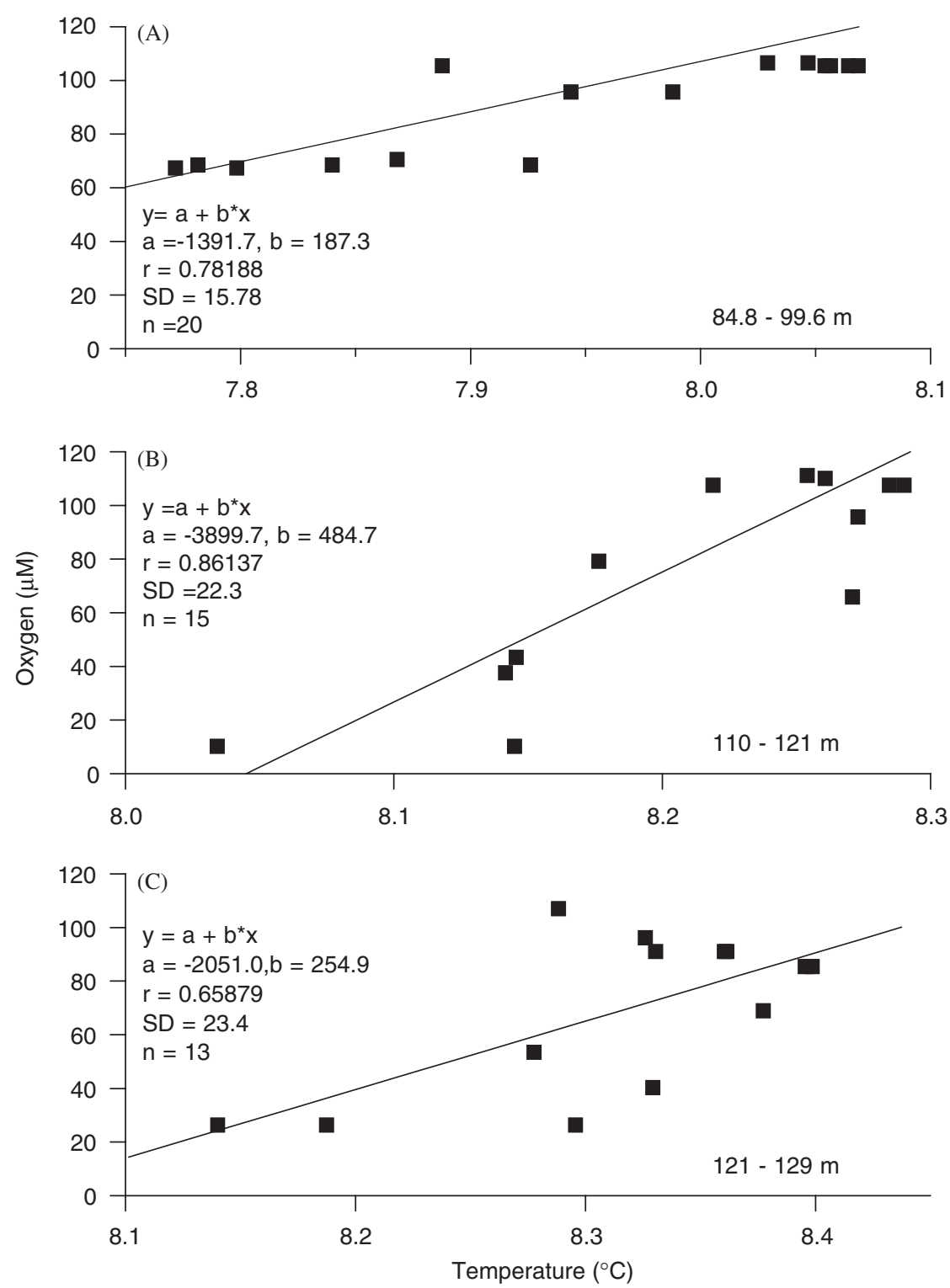

Fig. 5. Linear regressions for temperature and $\mathrm{O}_{2}$ each of three prominent oxygen injection layers observed at Station 162-16-9, 29 May 2001.

more than $100 \mu \mathrm{M}$, high-resolution oxygen profiling should be the best way to trace lateral intrusions.

In contrast to the frequent, strong disruption of the suboxic layer in the southwest stations, the westcentral and northwest stations revealed more stable transitions between oxic and sulfidic waters. And, as a result of the physical gyre circulation (doming of the waters in the central regions; Konovalov et al., 2003), the onset of $\mathrm{H}_{2} \mathrm{~S}$ was considerably shallower at the central station (Fig. 1: 162-16-6, 162-17-2 and 162-17-13) than in the southwest or northwest stations. At the west-central station (162-17-2), oxygen was nondetectable by $79 \mathrm{~m}\left(\sigma_{\mathrm{t}}\right.$ of 15.55$)$ and the $\mathrm{H}_{2} \mathrm{~S}$ onset was at $105 \mathrm{~m}\left(\sigma_{\mathrm{t}}\right.$ of 16.07) (Fig. 6A). Furthermore, no well-structured lateral oxygen intrusions were visible within the profile, and a stable, well-defined suboxic zone existed for greater than $30 \mathrm{~m}$.

Data from the northwest station (Fig. 1: 162-173 ) illustrates the gyre effect. Oxygen was detected to $101 \mathrm{~m}\left(\sigma_{\mathrm{t}}\right.$ of 15.45$)$ and the onset of $\mathrm{H}_{2} \mathrm{~S}$ was not until $139 \mathrm{~m}\left(\sigma_{\mathrm{t}}\right.$ of 16.10) (Fig. 6B). Note the 
consistent values of $\sigma_{\mathrm{t}}$ between these two stations. Again, no lateral oxygen intrusions are present throughout the profile, and a stable, well-defined suboxic zone exists for nearly $40 \mathrm{~m}$. There is no general shelf-break effect. The anomalies seen at Station 162-16-9 appear to be generated by the Bosporus Plume alone.

The data in Fig. 6A and B also illustrate the good agreement between in situ voltammetric measurements, on-deck voltammetric measurements in line with the pump profiler outflow, and volumetric titration measurements made from CTD rosette sampling immediately following in situ/pump casts. Minor offsets between flow cell voltammetry and in situ voltammetry may be attributable to time variations in matching waters delivered to the deck from specific density surfaces (depths).

\subsection{Reduced sulfur species}

Sulfide oxidation results in formation of polysulfides $\left(\mathrm{S}_{x}^{2-}\right)$, elemental sulfur $\left(\mathrm{S}_{8}\right)$, thiosulfate $\left(\mathrm{S}_{2} \mathrm{O}_{3}^{2-}\right)$, and polythionates (e.g., tetrathionate,
$\mathrm{S}_{4} \mathrm{O}_{6}^{2-}$ ), all of which have been recently observed in field studies (Luther et al., 2001a,b). When analyzed with voltammetry, these sulfur species, except for polysulfides) give a single peak. At slow scan rates, $\mathrm{H}_{2} \mathrm{~S}, \mathrm{~S}_{8}$, and polysulfides overlap to give a single peak at about $-0.6 \mathrm{~V}$ (Luther et al., 1985; Wang and Tessier, 1998; Rozan et al., 2000). However, polysulfides are unique because the sulfur exists in two oxidation states and it is possible to discriminate each oxidation state with fast potential scans (Rozan et al., 2000). At a potential more positive than $-0.6 \mathrm{~V}, \mathrm{~S}_{x}^{2-}$ reacts to form an $\mathrm{HgS}_{x}$ species at the $\mathrm{Au} / \mathrm{Hg}$ electrode, which is an electrochemical oxidation of the $\mathrm{Hg}$. Scanning negatively then results in $\mathrm{HgS}_{x}$ reduction to $\mathrm{Hg}$ and $\mathrm{S}_{x}^{2-}$ and this signal overlaps with $\mathrm{H}_{2} \mathrm{~S}$ and $\mathrm{S}_{8}$. The $(x-1) S^{0}$ atoms of $S_{x}^{2-}$ are then reduced to sulfide at a more negative potential, depending on scan rate. Since the reduction of $\mathrm{S}^{0}$ atoms in $\mathrm{S}_{x}^{2-}$ is irreversible, increasing scan rate results in a shift of the peak to a more negative potential, permitting a visual separation of the $\operatorname{HgS}_{x}$ reduction from the $\mathrm{S}(0)$ reduction in $\mathrm{S}_{x}^{2-}$ (Table 1 ).

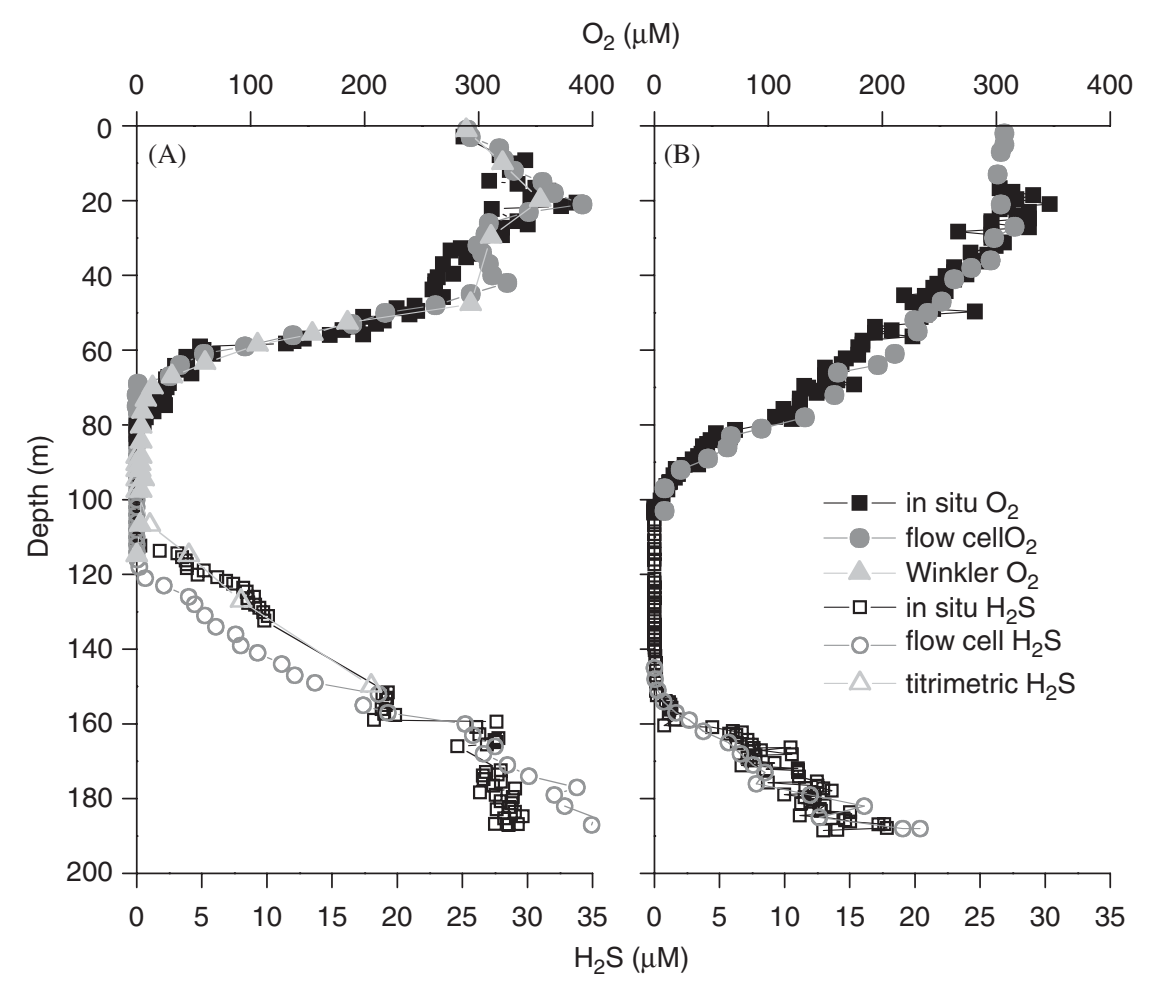

Fig. 6. A. Profile of Station 162-17-2 in the center of the western gyre on 2 June 2001; B. Profile of Station 162-17-3 near the NW shelf break on 4 June 2001. Note differences in $\mathrm{O}_{2}$ depletion and $\mathrm{H}_{2} \mathrm{~S}$ onset depths, as well as good agreement between various measurement techniques. 
At the base of the suboxic zone at 162-17-3 (Fig. 1,6B,7) we observed an indication of $\mathrm{S}_{x}^{2-}$. The voltammetric scan revealed a small, yet discernable split peak at $138.7 \mathrm{~m}$ (Fig. 7A and B). In panel A, a clear increase in signal current for $\mathrm{HS}^{-}$was observed with increase in depth, indicating an increase in sulfide concentration up to approximately $6 \mu \mathrm{M}$ at $163 \mathrm{~m}$. The peak shift to lower voltages with higher concentrations is in accordance with the Nernst equation (Luther and Ferdelman, 1993). Closer investigation of the scan at $138.7 \mathrm{~m}$ (Fig. 7B) reveals a subtle split peak with potentials of -0.636 and $-0.783 \mathrm{~V}$, indicating that $\mathrm{S}(0)$ and $\mathrm{S}$ (-II) as polysulfide, as well as $\mathrm{H}_{2} \mathrm{~S}$ were present. Less than $1 \mathrm{~m}$ deeper the split peak for $\mathrm{S}_{x}^{2-}$ was not present, indicating that the $\mathrm{H}_{2} \mathrm{~S}$ boundary had been crossed after descending through a thin layer of $\mathrm{S}_{x}^{2-}$. The factors that determine the exact depth of this

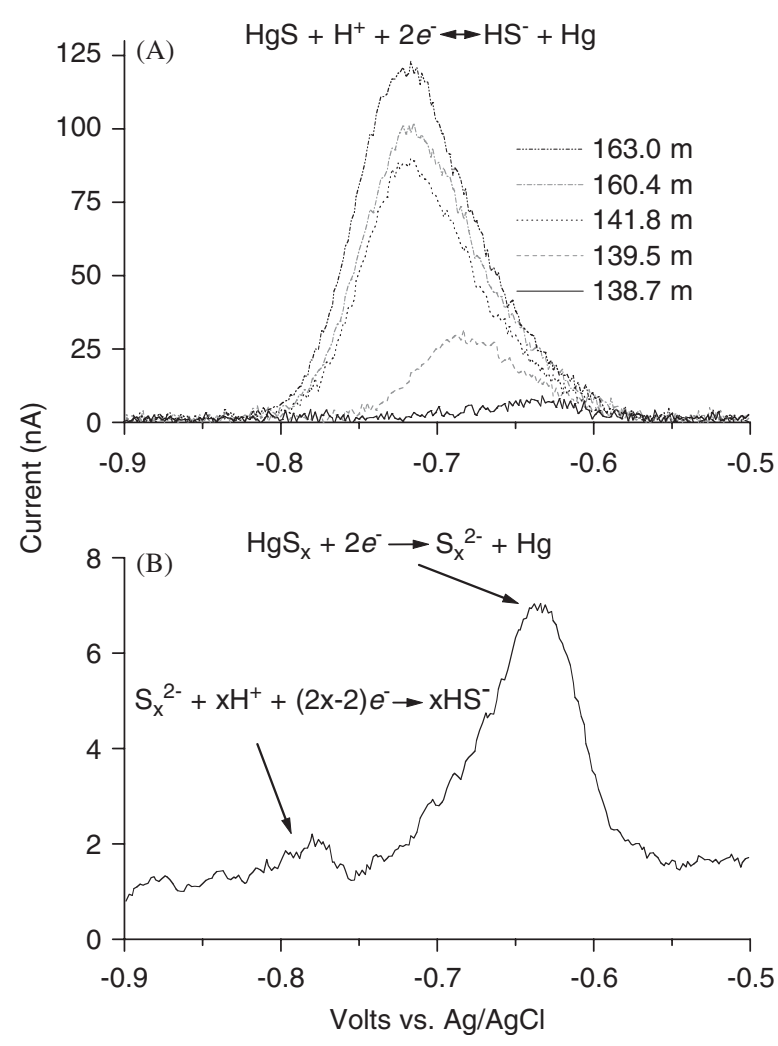

Fig. 7. Representative in situ voltammograms (expanded around $\mathrm{HS}^{-}$peak) depicting sulfide onset and polysulfide presence at Station $162-17-3$ on 4 June 2001. The peaks observed in panel B consist of a mix of sulfide and polysulfide. The peak at $-0.64 \mathrm{~V}$ represents both sulfide and polysulfide, while the smaller peak at $-0.78 \mathrm{~V}$ is attributable to only polysulfide. thin layer are still uncertain but may be related to Mn cycling.

\subsection{Manganese distributions}

Such partially oxidized sulfur species probably exist throughout the Black Sea at redox transitions where both an oxidant such as $\mathrm{Mn}$ (III/IV) and a reductant such as $\mathrm{H}_{2} \mathrm{~S}$ can be found or where microbial mediation can occur. However, production of sulfur intermediates in Black Sea waters under typical anoxic conditions should lead to their rapid uptake or disproportionation by organisms requiring them for an energy source (Jorgensen et al., 1991). Their transient nature makes the stable suboxic zone of the northwest more ideal for observing them. In contrast, the southwest station exhibited more temporal variability, and therefore intermediate species would be expected to be even more transient and difficult to measure. Four profiles from the southwest stations are shown for 29 May (Fig. 8A), 30 May (Fig. 8B), 31 May (Fig. 8C), and 9 June (Fig. 8D). Profiles are shown versus density to remove doming effects or vertical shifts in the water column and to better resolve variability within the transition between oxic and sulfidic waters (for reference, Fig. 8A shows the same data plotted versus depth in Fig. 6A). Over the 3-day period between 29 and 31 May (Fig. 8A-C), much variability in temperature and oxygen was visible throughout the lower portion of the oxic zone, resulting in a very unstable, undeveloped suboxic zone of less than $5 \mathrm{~m}$ thickness. Oxygen disappeared over a range of $\sigma_{\mathrm{t}}$ from 15.8 to $16.18(130-155 \mathrm{~m})$. When this location was revisited on June 9 (Fig. 8D), far fewer lateral intrusions were present, resulting in lower overall oxygen concentrations. No welldeveloped suboxic zone had developed, and while oxygen disappearance was still located at $\sigma_{\mathrm{t}}$ of 15.99, its depth had shoaled to $122 \mathrm{~m}$. Similarly, the onset of $\mathrm{H}_{2} \mathrm{~S}$ varied between $\sigma_{\mathrm{t}}$ of 16.03 and 16.25 (or 120 and $164 \mathrm{~m}$ ). We note that the shallow $\mathrm{H}_{2} \mathrm{~S}$ onset at $\sigma_{\mathrm{t}}$ of 16.03 (125 m, Fig. 8D) was accompanied by only trace levels of $\mathrm{H}_{2} \mathrm{~S}(<1 \mu \mathrm{M})$ and alternating, suboxic layers down to $\sigma_{\mathrm{t}}$ of 16.33 $(152 \mathrm{~m})$, perhaps indicating that an oxidation due to lateral injection had occurred, creating two sulfide zones, similar to those clearly seen in Figs. 8A,3A and $3 \mathrm{~B}$.

In contrast, the west-central station showed much less variability in a sequence of different profiles 


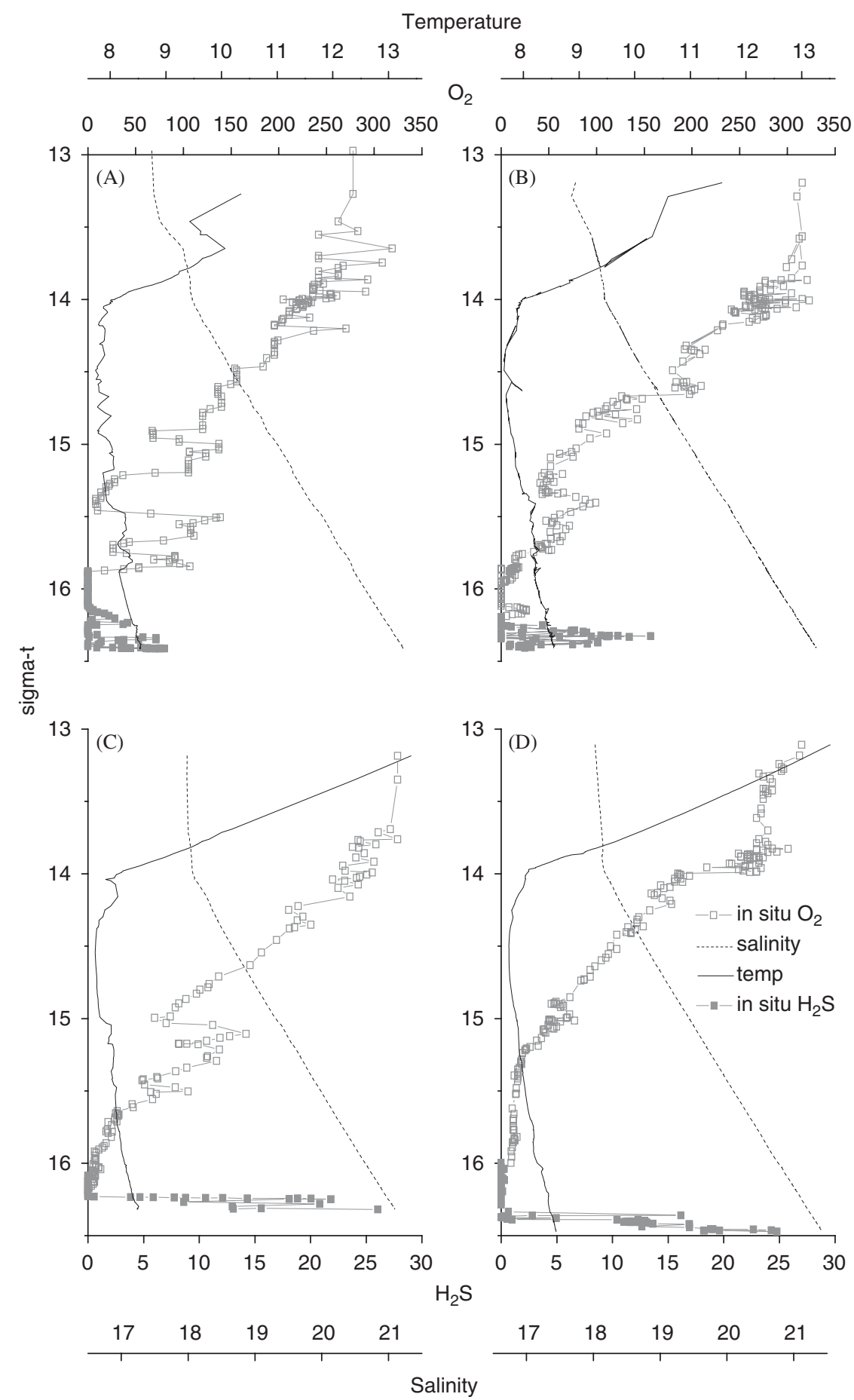

Fig. 8. Density versus high-resolution in situ voltammetric $\mathrm{O}_{2}$ and $\mathrm{H}_{2} \mathrm{~S}$ data coupled to CTD data from the MBARI unit in the southwest through time. A. Station 162-16-9 on 29 May 2001; B. Station 162-16-10 on 30 May 2001; C. Station 162-16-10.2 on 31 May 2001; D. Station 162-17-14 on 9 June 2001.

(i.e. no well-established fingers of oxygen intrusion) but did show variability in the density of oxygen penetration versus time. Fig. 9A and B show profiles from 2 and 8 June, respectively, during which oxygen penetration shoaled from $\sigma_{\mathrm{t}}$ of $15.55(79 \mathrm{~m})$ to $15.39(72 \mathrm{~m}) . \mathrm{H}_{2} \mathrm{~S}$ onset stayed relatively constant 


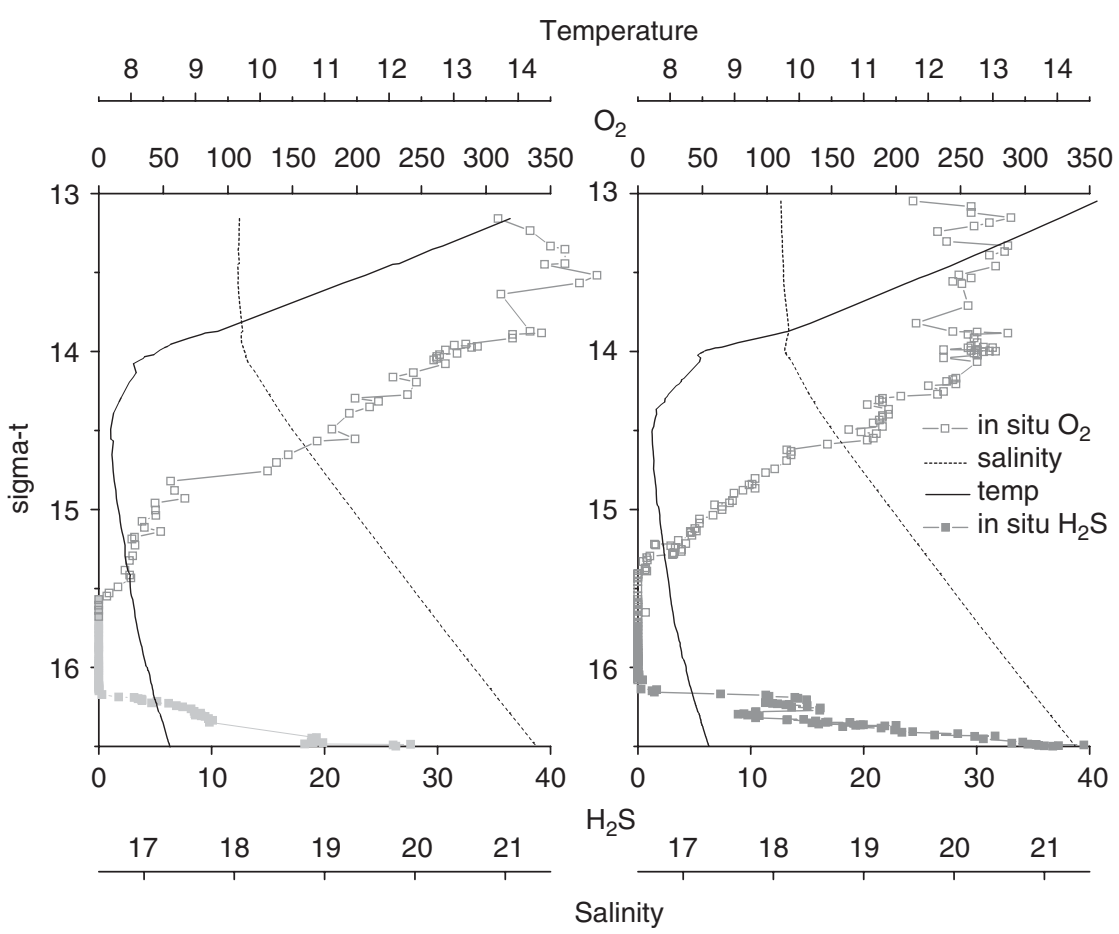

Fig. 9. Density versus high-resolution in situ voltammetric $\mathrm{O}_{2}$ and $\mathrm{H}_{2} \mathrm{~S}$ data coupled to CTD data from the MBARI unit for: A. Station 162-17-2 on 2 June 2001; B. Station 162-17-13 on 8 June 2001.

at $\sigma_{\mathrm{t}}$ of $16.11(106 \mathrm{~m})$ and $16.07(105 \mathrm{~m})$. The possible explanation for the depressed oxygen penetration seen on 2 June is lateral oxygen influx, as a small temperature anomaly was observed at $\sigma_{\mathrm{t}}$ 15.43. Thus, we conclude that lateral influx of oxygen associated with the Bosporus plume significantly affects the redox budget in the westcentral basin, as first proposed by Konovalov et al. (2001) and changes the distribution of the main redox species.

\subsection{Suboxic zone distributions and maintenance}

Eight in situ voltammetric profiles were made during the 2001 R.V. Knorr cruise. In all profiles a suboxic zone was present, but the vertical distributions as well as overall thickness of the suboxic zone varied as a result of proximity to the Bosporus inflow (Table 2). Comparisons between the westcentral, northwest and southwest stations reveal that the depth and density surface at which oxygen disappears and sulfide appears are significantly different (Table 3). The overall thickness of the suboxic zone was significantly less in the southwest than in the west-central in terms of density, and the $p$-value statistic of 0.512 were inconclusive for depth. Northwest stations did not vary significantly from west-central stations in any of the pairwise comparisons. Interestingly, northwest and southwest stations only significantly varied in terms of density surfaces for $\mathrm{O}_{2}$ disappearance and $\mathrm{H}_{2} \mathrm{~S}$ onset. This is most likely a result of the effect of the Rim Current acting to deepen density surfaces in both the southwest and the northwest (Oguz et al., 1993; Ginzburg et al., 2002).

In situ voltammetry cannot measure particulate species, and its detection limit for dissolved manganese is $5 \mu \mathrm{M}$. Thus, traditional wet chemical techniques were employed to investigate the distribution and concentration of dissolved and particulate $\mathrm{Mn}$ and particulate $\mathrm{S}_{8}$. Dissolved $\mathrm{Mn}$ (II) data agree with Lewis and Landing (1991) and Tebo (1991) in terms of onset depth $/ \sigma_{t}$, concentration, and profile shape (Fig. 10B, D, F). In the northwest and west-central Black Sea, the major onset of dissolved $\mathrm{Mn}$ was roughly $\sigma_{\mathrm{t}}=$ 15.8-15.9, but showed variability and suppression down to $\sigma_{\mathrm{t}}=16.3$ in the southwest, as seen for $\mathrm{O}_{2}$. 
Table 2

Suboxic zone thickness in terms of density $\left(\sigma_{\mathrm{t}}\right)$ and depth $(\mathrm{m})$

\begin{tabular}{|c|c|c|c|c|c|c|c|}
\hline \multirow[t]{2}{*}{ Station } & \multirow[t]{2}{*}{ Date } & \multicolumn{2}{|c|}{$\mathrm{O}_{2}$ disappearance } & \multicolumn{2}{|c|}{$\mathrm{H}_{2} \mathrm{~S}$ onset } & \multicolumn{2}{|c|}{ Suboxic zone thickness } \\
\hline & & $\sigma_{\mathrm{t}}$ & Depth & $\sigma_{\mathrm{t}}$ & Depth & $\sigma_{\mathrm{t}}$ & Depth \\
\hline $162-17-3$ & 4 June 2001 & 15.45 & 101 & 16.1 & 139 & 0.65 & 38 \\
\hline $162-17-12$ & 7 June 201 & 15.64 & 124 & 16.04 & 158 & 0.4 & 34 \\
\hline $162-17-2$ & 2 June 2001 & 15.55 & 79 & 16.11 & 106 & 0.56 & 27 \\
\hline $162-17-13$ & 8 June 2001 & 15.39 & 72 & 16.07 & 105 & 0.68 & 33 \\
\hline $162-16-9$ & 29 May 2001 & 15.8 & 130 & 16.13 & 151 & 0.33 & 21 \\
\hline $162-16-10$ & 30 May 2001 & 16.18 & 153 & 16.25 & 164 & 0.07 & 11 \\
\hline $162-16-10.2$ & 31 May 2001 & 16.17 & 155 & 16.23 & 160 & 0.06 & 5 \\
\hline $162-17-14$ & 9 June 2001 & 15.99 & 122 & 16.33 & 152 & 0.34 & 30 \\
\hline
\end{tabular}

In situ data were acquired by voltammetry from the in situ electrochemical analyzer coupled to the pump profiler package (detection limits of $3 \mu \mathrm{M}$ for $\mathrm{O}_{2}$ and $30 \mathrm{nM}$ for $\mathrm{H}_{2} \mathrm{~S}$ ). Normal typeface represents northwest stations, boldface are the west-central stations, and italicized are southwest stations.

Table 3

Comparisons of in situ voltammetry suboxic zone profiles among stations from the northwest, west-central, and southwest Black Sea

\begin{tabular}{lll}
\hline Comparison & Parameter & $p$-value \\
\hline NW-WC & $\mathrm{O}_{2}$ disappearance $\left(\sigma_{\mathrm{t}}\right)$ & 0.3036 \\
& $\mathrm{O}_{2}$ disappearance $(\mathrm{m})$ & 0.1000 \\
& $\mathrm{H}_{2} \mathrm{~S}$ onset $\left(\sigma_{\mathrm{t}}\right)$ & 0.3174 \\
& $\mathrm{H}_{2} \mathrm{~S}$ onset $(\mathrm{m})$ & 0.0693 \\
& Suboxic thickness $\left(\sigma_{\mathrm{t}}\right)$ & 0.3088 \\
& Suboxic thickness $(\mathrm{m})$ & 0.1190 \\
& $\mathrm{O}_{2}$ disappearance $\left(\sigma_{\mathrm{t}}\right)$ & $\mathbf{0 . 0 1 6 5}$ \\
NW-SW & $\mathrm{O}_{2}$ disappearance $(\mathrm{m})$ & 0.0958 \\
& $\mathrm{H}_{2} \mathrm{~S}$ onset $\left(\sigma_{\mathrm{t}}\right)$ & $\mathbf{0 . 0 1 5 8}$ \\
& $\mathrm{H}_{2} \mathrm{~S}$ onset $(\mathrm{m})$ & 0.2805 \\
& Suboxic thickness $\left(\sigma_{\mathrm{t}}\right)$ & 0.0791 \\
& Suboxic thickness $(\mathrm{m})$ & $\mathbf{0 . 0 1 5 2}$ \\
& $\mathrm{O}_{2}$ disappearance $\left(\sigma_{\mathrm{t}}\right)$ & $\mathbf{0 . 0 0 9 1}$ \\
WC-SW & $\mathrm{O}_{2}$ disappearance $(\mathrm{m})$ & $\mathbf{0 . 0 0 1 0}$ \\
& $\mathrm{H}_{2} \mathrm{~S}$ onset $\left(\sigma_{\mathrm{t}}\right)$ & $\mathbf{0 . 0 1 6 9}$ \\
& $\mathrm{H}_{2} \mathrm{~S}$ onset $(\mathrm{m})$ & $\mathbf{0 . 0 0 0 3}$ \\
& Suboxic thickness $\left(\sigma_{\mathrm{t}}\right)$ & $\mathbf{0 . 0 0 6 5}$ \\
& Suboxic thickness $(\mathrm{m})$ & 0.0512 \\
\hline
\end{tabular}

$p$-value results from two-sample $t$ test assuming unequal variances and $\alpha=0.05$. Significant differences are in boldface.

Particulate Mn concentrations were up to 12 times greater in the southwest versus the west-central and northwest Black Sea (Fig. 10A, C, E).

Because manganese cycling in oxic/anoxic marine systems is tightly coupled with sulfide/elemental sulfur/sulfate cycling (Luther et al., 1991; Millero,
1991), it is also important to consider elemental sulfur distributions and concentrations. $\mathrm{MnO}_{2}$ can serve as an oxidant for $\mathrm{H}_{2} \mathrm{~S}$ after dissolved $\mathrm{Mn}^{2+}$ is oxidized to particulate $\mathrm{Mn}(\mathrm{III}, \mathrm{IV})$ above the anoxic layer and sinks back into the sulfidic zone (Tebo, 1991). $\mathrm{Mn}^{2+}$ can catalyze the oxidation of $\mathrm{H}_{2} \mathrm{~S}$ by $\mathrm{O}_{2}$ when $\mathrm{Mn}^{2+}$ and $\mathrm{O}_{2}$ co-exist in the same water mass (Luther et al., 1991). In most of the Black Sea away from the southwest region, elemental sulfur profiles generally showed subsurface maxima (concentrations less than $150 \mathrm{nM}$ ) just below the particulate Mn maxima and just above the onset of sulfide, in agreement with data from 1988 (Jorgensen et al., 1991; Luther et al., 1991). Sulfide oxidation was more intense and elemental sulfur at higher concentrations (Fig. 11) in the southwest Black Sea due to lateral influx of $\mathrm{O}_{2}$ above and below the $\mathrm{H}_{2} \mathrm{~S}$ onset. Particulate $\mathrm{Mn}$ was found within the sulfide zone (i.e. Fig. 10E,F compared with Fig. 8A) and it coincided with the maximum in elemental sulfur (Fig. 11), consistent with $\mathrm{O}_{2}$ oxidation of $\mathrm{Mn}(\mathrm{II})$ to $\mathrm{Mn}(\mathrm{III}, \mathrm{IV})$ in turn oxidizing $\mathrm{H}_{2} \mathrm{~S}$ to polysulfide and $\mathrm{S}_{8}$. Because the reaction of $\mathrm{MnO}_{2}$ with $\mathrm{H}_{2} \mathrm{~S}$ is fast and $\mathrm{S}_{8}$ is measurable as shown in Table 1 (Eqs. (3a,b)), these data indicate that the $\mathrm{Au} / \mathrm{Hg}$ electrode was measuring traces of soluble $\mathrm{S}_{8}$ at the $\mathrm{H}_{2} \mathrm{~S}$ onset in the southwest Black Sea.

\section{Conclusions}

High-resolution voltammetric profiling coupled to techniques for measurement validation resulted 

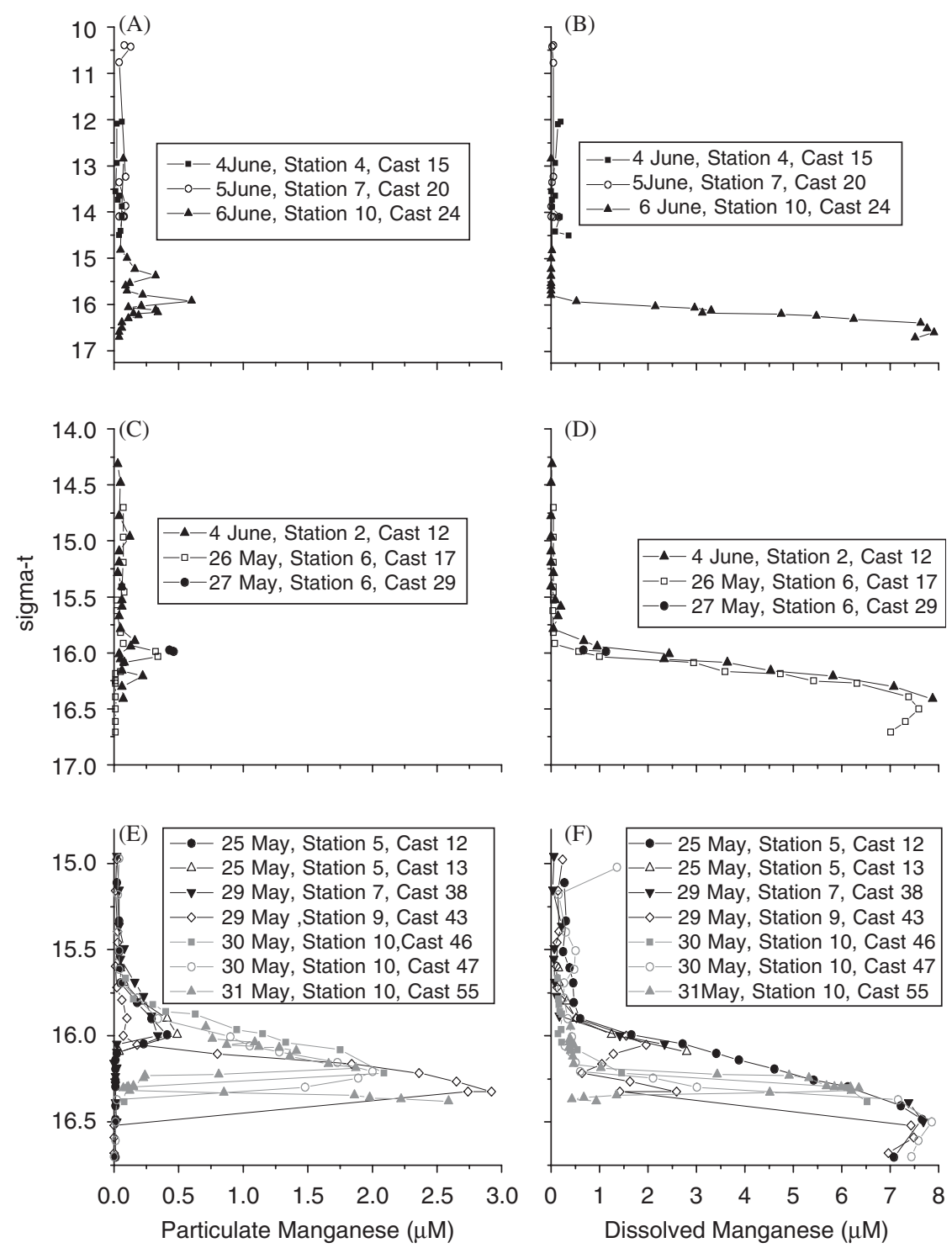

Fig. 10. A. Particulate Mn in the northwest Black Sea, B. Dissolved Mn in the northwest, C. Particulate Mn in the west-central, D. Dissolved Mn in the west-central, E. Particulate Mn in the southwest, F. Dissolved Mn in the southwest.

in an unprecedented high-resolution characterization of the oxic-suboxic-sulfidic transition throughout the western Black Sea, including measurement of partially oxidized sulfur intermediates just above onset of $\mathrm{H}_{2} \mathrm{~S}$. Increased intensity in sulfide oxidation was observed in southwest stations as a result of oxygen-rich ventilation by the Bosporus Plume, indicated by deep oxygen penetration (mean $\sigma_{\mathrm{t}}$ of 16.0 in the southwest as compared to 15.5 in the west-central and northwest) and suppression of $\mathrm{H}_{2} \mathrm{~S}$ onset (mean $\sigma_{\mathrm{t}}$ of 16.2 in the southwest as compared to 16.1 in the west-central and northwest). The thickness of the suboxic zone also varied, with a significantly thinner zone in the southwest. However, at no time was sulfide observed to coexist with oxygen, indicating that an alternative oxidant must be responsible for sulfide oxidation in the Black Sea. Mn(III/IV) phases are most likely the direct oxidants of $\mathrm{H}_{2} \mathrm{~S}$, while $\mathrm{O}_{2}$ is the ultimate oxidant via $\mathrm{Mn}(\mathrm{II})$ catalysis (Luther et al., 1991; Millero, 1991; Tebo, 1991; Konovalov and Murray, 2002). 

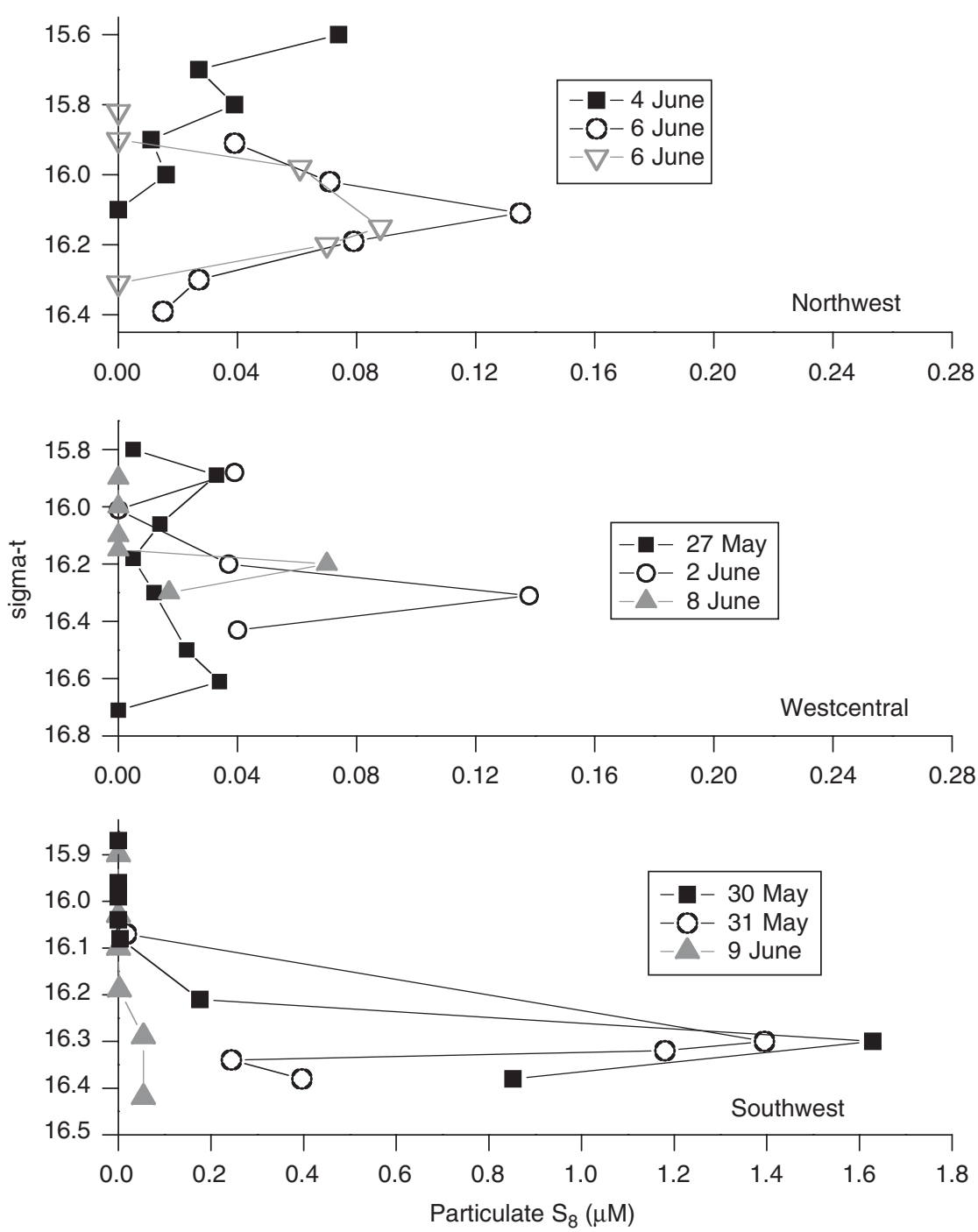

Fig. 11. Particulate $S_{8}$ in the northwest, west-central, and southwest Black Sea. Note concentration change between A, B versus C.

\section{Acknowledgments}

We thank the crew and captain of the R.V. Knorr for their help. This work was funded by grants from the National Science Foundation to G.W.L. (OCE0096365), B.M.T. (OCE-0221500 and EAR9725845), and James W. Murray (OCE-9906656), as well as the US Civilian Research and Development Foundation to S.K.K., A.S.R., and G.W.L. (UG2-2080).

\section{References}

Anderson, L.G., Dyrssen, D., Hall, P.O.J., 1988. On the sulphur chemistry of a super-anoxic fjord, framvaren, South Norway. Marine Chemistry 23, 283-293.
Arthur, M.A., Dean, W.E., 1998. Organic-matter production and preservation and evolution of anoxia in the Holocene Black Sea. Paleoceanography 13 (4), 395.

Brendel, P.J., Luther III, G.W., 1995. Development of a gold amalgam voltammetric microelectrode for the determination of dissolved $\mathrm{Fe}, \mathrm{Mn}, \mathrm{O} 2$, and $\mathrm{S}(-\mathrm{II})$ in porewaters of marine and freshwater sediments. Environmental Science and Technology 29 (3), 751-761.

Brewer, P.G., Spencer, D.W., 1971. Colorimetric determination of manganese in anoxic waters. Limnology and Oceanography 16 (1), 107-110.

Bull, D.C., Taillefert, M., 2001. Seasonal and topographic variations in porewaters of a southeastern USA salt marsh as revealed by voltammetric profiling. Geochemical Transactions $13,173$.

Codispoti, L.A., Friederich, G.E., Murray, J.W., Sakamoto, C.M., 1991. Chemical variability in the Black Sea: implications of data obtained with a continuous vertical profiling system that penetrated the oxic-anoxic interface. Deep Sea 
Research Part II: Topical Studies in Oceanography 38, S691-S710.

Faschuck, D.Y., Ayzatullin, T.A., 1986. A possible transformation of the anaerobic zone of the Black Sea. Oceanology (Russian) 26, 171-178.

Ginzburg, A.I., Kostianoy, A.G., Nezlin, N.P., Soloviev, D.M., Stanichny, S.V., 2002. Anticyclonic eddies in the northwestern Black Sea. Journal of Marine Systems 32 (1-3), 91-106.

Glazer, B.T., Cary, S.C., Hohmann, L., Luther III, G.W., 2002. In situ sulfur speciation using $\mathrm{Au} / \mathrm{Hg}$ microelectrodes as an aid to microbial characterization of an intertidal salt marsh microbial mat. In: Taillefert, M., Rozan, T.F. (Eds.), Environmental Electrochemistry: Analyses of Trace Element Biogeochemistry. American Chemical Society, Washington, DC.

Ivanov, L.I., Samodurov, A.S., 2001. The role of lateral fluxes in ventilation of the Black Sea. Journal of Marine Systems 31 (1-3), 159-174.

Jorgensen, B.B., Fossing, H., Wirsen, C., Jannasch, H., 1991. Sulfide oxidation in the anoxic Black Sea chemocline. DeepSea Research Part II: Topical Studies in Oceanography 38 (Suppl. 2), S1083-S1103.

Konovalov, S.K., Ivanov, L.I., Samodurov, A.S., 2001. Fluxes and budget of sulphide and ammonia in the Black Sea anoxic layer. Journal of Marine Systems 31 (1-3), 203-216.

Konovalov, S.K., Luther III, G.W., Friederich, G.E., Nuzzio, D.B., Tebo, B., Murray, J.W., Oguz, T., Glazer, B.T., Trouwborst, R.E., Clement, B.G., Murray, K.J., Romanov, A.S., 2003. Lateral injection of oxygen with the Bosporus plume-fingers of oxidizing potential in the Black Sea. Limnology and Oceanography 48 (6), 2369-2376.

Konovalov, S.K., Murray, J.W., 2002. Variations in the chemistry of the Black Sea on a time scale of decades (1960-1995). Journal of Marine Systems 31 (1-3), 217-243.

Lane-Serff, G.F., Rohling, E.J., Bryden, H.L., Charnock, H., 1997. Postglacial connection of the Black Sea to the Mediterranean and its relation to the timing of sapropel formation. Paleoceanography 12 (2), 169-174.

Latif, M.A., Ozsoy, E., Oguz, T., Unluata, U., 1991. Observations of the Mediterranean inflow into the Black Sea. Deep Sea Research Part II: Topical Studies in Oceanography 38 (2), S711-S723.

Lewis, B., Landing, W., 1991. The biogeochemistry of manganese and iron in the Black Sea. Deep Sea Research II: Topical Studies in Oceanography 38, S773-S804.

Luther III, G.W., Bono, A.B., Taillefert, M., 2002. A continuous flow electrochemical cell for analysis of chemical species and ions at high pressure: laboratory, shipboard and hydrothermal vent results. In: Taillefert, M., Rozan, T.F. (Eds.), Environmental Electrochemistry: Analyses of Trace Element Biogeochemistry. American Chemical Society, Washington, DC, pp. 54-73.

Luther III, G.W., Church, T.M., Powell, D., 1991. Sulfur speciation and sulfide oxidation in the water column of the Black Sea. Deep Sea Research Part II: Topical Studies in Oceanography 38, S1121-S1138.

Luther III, G.W., Ferdelman, T.G., 1993. Voltammetric characterization of iron (II) sulfide complexes in laboratory solutions and in marine waters and porewaters. Environmental Science and Technology 27, 1154-1163.
Luther III, G.W., Giblin, A.E., Varsolona, R., 1985. Polarographic analysis of sulfur species in marine porewaters Limnology and Oceanography 30 (4), 727-736.

Luther III, G.W., Reimers, C.E., Nuzzio, D.B., Lovalvo, D., 1999. In situ deployment of voltammetric, potentiometric, and amperometric microelectrodes from a ROV to determine dissolved $\mathrm{O}_{2}, \mathrm{Mn}, \mathrm{Fe}, \mathrm{S}(-2)$, and $\mathrm{pH}$ in porewaters. Environmental Science and Technology 33, $4352-4356$.

Luther III, G.W., Glazer, B.T., Hohmann, L., Popp, J.I., Taillefert, M., Rozan, T.F., Brendel, P.J., Theberge, S.M., Nuzzio, D.B., 2001a. Sulfur speciation monitored in situ with solid state gold amalgam voltammetric microelectrodes: polysulfides as a special case in sediments, microbial mats and hydrothermal vent waters. Journal of Environmental Monitoring 3 (1), 61-66.

Luther III, G.W., Rozan, T.F., Taillefert, M., Nuzzio, D.B., D Meo, C., Shank, T.M., Lutz, R.A., Cary, S.C., $2001 \mathrm{~b}$. Chemical speciation drives hydrothermal vent ecology. Nature 410 (6830), 813-816.

Millero, F.J., 1991. The oxidation of $\mathrm{H}_{2} \mathrm{~S}$ in Black Sea waters. Deep Sea Research Part II: Topical Studies in Oceanography 38, S1139-S1150.

Murray, J.W., Codispoti, L.A., Friederich, G.E., 1995. Oxidation-reduction environments: the suboxic zone in the Black Sea. In: Huang, C.P., O’Melia, C.R., Morgan, J.J. (Eds.), Aquatic Chemistry: Interfacial and Interspecies Processes, vol. 244. American Chemical Society, Washington, DC, pp. $157-176$.

Murray, J.W., Jannasch, H.W., Honjo, S., Anderson, R.F., Reeburgh, W.S., Top, Z., Friederich, G.E., Codispoti, L.A., Izdar, E., 1989. Unexpected changes in the oxicanoxic interface in the Black Sea. Nature 338, 411-413.

Murray, J.W., Top, Z., Ozsoy, E., 1991. Hydrographic properties and ventilation of the Black Sea. Deep-Sea Research Part II: Topical Studies in Oceanography 38 (Suppl. 2A), 663-689.

Oguz, T., Latun, V.S., Latif, M.A., Vladimirov, V.V., Sur, H.I., Markov, A.A., Ozsoy, E., Kotovshchikov, B.B., Eremeev, V.V., Unluata, U., 1993. Circulation in the surface and intermediate layers of the Black Sea. Deep Sea Research Part I: Oceanographic Research Papers 40 (8), 1597-1612.

Oguz, T., Rozman, L., 1991. Characteristics of the Mediterranean underflow in the southwestern Black Sea continental shelf/slope region. Oceanology Acta 14 (5), 433-444.

Pers, C., Rahm, L., 2000. Changes in apparent oxygen removal in the Baltic proper deep water. Journal of Marine Systems 25, 421-429.

Rozan, T.F., Luther III, G.W., 2001. An anion chromatography/ ultraviolet detection method to determine nitrite, nitrate, and sulfide concentrations in saline (pore) waters. Marine Chemistry 77 (1), 1-6.

Rozan, T.F., Theberge, S.M., Luther III, G.W., 2000. Quantifying elemental sulfur $\left(\mathrm{S}^{0}\right)$, bisulfide $\left(\mathrm{HS}^{-}\right)$and polysulfides $\left(\mathrm{S}_{x}^{2-}\right)$ using a voltammetric method. Analytica Chimica Acta 415 (1-2), 175-184.

Schuf, J., De Baar, H.J.W., 1995. Rare earth element exchange through the Bosporus: The Black Sea as a net source of REEs to the Mediterranean Sea. Geochimica et Cosmochimica Acta 59 (17), 3503-3509.

Scranton, M.I., Astor, Y., Bohrer, R., Ho, T.-Y., Muller-Karger, F., 2001. Controls on temporal variability of the geochemistry 
of the deep Cariaco Basin. Deep Sea Research Part I: Oceanographic Research Papers 48 (7), 1605-1625.

Sorokin, Y.I., 1972. The bacterial population and the processes of hydrogen sulfide oxidation in the Black Sea. Journal du Conseil International Exploration de la Mer 34, $423-454$.

Sorokin, Y.I., 1983. The Black Sea. In: Ketchum, B.H. (Ed.), Ecosystems of the World 26: Estuaries and Enclosed Seas. Amsterdam, Elsevier.
Tebo, B., 1991. Manganese (II) oxidation in the suboxic zone of the Black Sea. Deep-Sea Research Part II: Topical Studies in Oceanography 38 (Suppl. 2), S883-S905.

Tugrul, S., Basturk, O., Saydam, C., Yilmaz, A., 1992. Changes in the hydrochemistry of the Black Sea inferred from water density profiles. Nature 359, 137-139.

Wang, F., Tessier, A., 1998. Voltammetric determination of elemental sulfur in pore waters. Limnology and Oceanography 43 (6), 1353-1361. 